\title{
Characteristics of greenhouse gas emission in three full-scale wastewater treatment processes
}

\author{
Xu Yan, Lin Li, Junxin Liu* \\ Department of Water Pollution Control Technology, Research Center for Eco-Environmental Sciences, Chinese Academy of Sciences, Beijing 100085, \\ China.E-mail: yanxu119@126.com
}

\section{A R T I C L E I N F O}

\section{Article history:}

Received 15 March 2013

revised 31 July 2013

accepted 02 August 2013

Keywords:
wastewater treatment
greenhouse gas
carbon dioxide
methane
nitrous oxide
emission factor
DOI: $10.1016 / \mathrm{S} 1001-0742(13) 60429-5$

\begin{abstract}
A B S T R A C T
Three full-scale wastewater treatment processes, Orbal oxidation ditch, anoxic/anaerobic/aerobic (reversed $\mathrm{A}^{2} \mathrm{O}$ ) and anaerobic/anoxic/aerobic $\left(\mathrm{A}^{2} \mathrm{O}\right)$, were selected to investigate the emission characteristics of greenhouse gases $(\mathrm{GHG})$, including carbon dioxide $\left(\mathrm{CO}_{2}\right)$, methane $\left(\mathrm{CH}_{4}\right)$ and nitrous oxide $\left(\mathrm{N}_{2} \mathrm{O}\right)$. Results showed that although the processes were different, the units presenting high GHG emission fluxes were remarkably similar, namely the highest $\mathrm{CO}_{2}$ and $\mathrm{N}_{2} \mathrm{O}$ emission fluxes occurred in the aerobic areas, and the highest $\mathrm{CH}_{4}$ emission fluxes occurred in the grit tanks. The GHG emission amount of each unit can be calculated from its area and GHG emission flux. The calculation results revealed that the maximum emission amounts of $\mathrm{CO}_{2}, \mathrm{CH}_{4}$ and $\mathrm{N}_{2} \mathrm{O}$ in the three wastewater treatment processes appeared in the aerobic areas in all cases. Theoretically, $\mathrm{CH}_{4}$ should be produced in anaerobic conditions, rather than aerobic conditions. However, results in this study showed that the $\mathrm{CH}_{4}$ emission fluxes in the forepart of the aerobic area were distinctly higher than in the anaerobic area. The situation for $\mathrm{N}_{2} \mathrm{O}$ was similar to that of $\mathrm{CH}_{4}$ : the $\mathrm{N}_{2} \mathrm{O}$ emission flux in the aerobic area was also higher than that in the anoxic area. Through analysis of the GHG mass balance, it was found that the flow of dissolved GHG in the wastewater treatment processes and aerators may be the main reason for this phenomenon. Based on the monitoring and calculation results, GHG emission factors for the three wastewater treatment processes were determined. The $\mathrm{A}^{2} \mathrm{O}$ process had the highest $\mathrm{CO}_{2}$ emission factor of $319.3 \mathrm{~g} \mathrm{CO}_{2} / \mathrm{kg} \mathrm{COD}$ removed, and the highest $\mathrm{CH}_{4}$ and $\mathrm{N}_{2} \mathrm{O}$ emission factors of $3.3 \mathrm{~g} \mathrm{CH}_{4} / \mathrm{kg} \mathrm{COD}$ removed and $3.6 \mathrm{~g} \mathrm{~N}_{2} \mathrm{O} / \mathrm{kg} \mathrm{TN}_{\text {removed }}$ were observed in the Orbal oxidation ditch process.
\end{abstract}

\section{Introduction}

In wastewater treatment systems, organic contaminants are degraded into carbon dioxide $\left(\mathrm{CO}_{2}\right)$ and water under aerobic conditions, or transformed to methane $\left(\mathrm{CH}_{4}\right)$ under anaerobic conditions, and nitrous oxide $\left(\mathrm{N}_{2} \mathrm{O}\right)$ can be produced in biological nitrogen removal processes (Sahely et al., 2006; Kampschreur et al., 2009; Flores-Alsina et al., 2011). Additionally, the thickening and treatment of excess sludge can also result in $\mathrm{CH}_{4}$ emissions (Metcalf and Eddy,

\footnotetext{
${ }^{*}$ Corresponding author. E-mail: jxliu@ @rcees.ac.cn
}

2002; Forster-Carneiro et al., 2008; Yoshida et al., 2009; Zhu et al., 2009). Therefore, wastewater treatment plants (WWTPs) are recognized as one of the major sources of greenhouse gas (GHG) emissions (Doorm et al., 1997). Previous studies have provided some research data for $\mathrm{CO}_{2}, \mathrm{CH}_{4}$ and $\mathrm{N}_{2} \mathrm{O}$ emission from different WWTPs; however, large differences exist between data from different studies (Czepiel et al., 1993, 1995; IPCC, 1996; Eklund and LaCosse, 1998; Park et al., 2000; Kampschreur et al., 2008a, 2008b; Foley et al., 2010; Wang et al., 2011). Some studies have suggested that the GHG emission rates are significantly influenced by the operational conditions of wastewater treatment reactors, e.g. $\mathrm{N}_{2} \mathrm{O}$ emission rates 
were related to the carbon sources for denitrification (Chiu and Chung, 2000; Zeng et al., 2003; Li et al., 2008; Tallec et al., 2008), and residual nitrate nitrogen in the mixed liquid (Park et al., 2000). Ahn et al. (2010) suggested that the aerobic zones contributed more $\mathrm{N}_{2} \mathrm{O}$ emission than anoxic zones based on the results from 12 WWTPs; in addition, high nitrite, ammonium and dissolved oxygen concentrations were positively correlated with $\mathrm{N}_{2} \mathrm{O}$ emission from aerobic zones. According to the principles of biological wastewater treatment, the amounts of GHG emission from WWTPs are related to the type of wastewater treatment process. Through comparison of the GHG production obtained using aerobic or anaerobic treatment technology, Keller and Hartley (2003) demonstrated that the total GHG output could be reduced by changing from fully aerobic treatment to primarily anaerobic processes. However, the influence of the different wastewater treatment processes in full-scale WWTPs on total GHG emissions, including $\mathrm{CO}_{2}, \mathrm{CH}_{4}$ and $\mathrm{N}_{2} \mathrm{O}$, were ignored in previous studies.

In this study, three typical full-scale wastewater treatment processes, Orbal oxidation ditch, anoxic/anaerobic/aerobic (reversed $\mathrm{A}^{2} \mathrm{O}$ ), and anaerobic/anoxic/aerobic $\left(\mathrm{A}^{2} \mathrm{O}\right)$, were investigated to compare their GHG emission characteristics and determine GHG emission factors. Effects of seasonal variation on GHG emission in the three wastewater treatment processes were also considered during continuous monitoring over 9 months.

\section{Materials and methods}

\subsection{WWTPs descriptions and sampling locations}

A 9-month (from March to November) study on the characteristics of GHG emission in different wastewater treatment processes was conducted in two Beijing WWTPs, one of which used an Orbal oxidation ditch process, where the other included two processes, reversed $\mathrm{A}^{2} \mathrm{O}$ and $\mathrm{A}^{2} \mathrm{O}$ (Fig. 1). Information on the individual processes and their operational parameters is summarized in Table 1. The Orbal oxidation ditch process received both domestic and industrial wastewater, while the reversed $\mathrm{A}^{2} \mathrm{O}$ process and $\mathrm{A}^{2} \mathrm{O}$ process treated the same domestic wastewater. The sampling locations are illustrated in Fig. 1. $\mathrm{CO}_{2}, \mathrm{CH}_{4}$ and $\mathrm{N}_{2} \mathrm{O}$ fluxes at each sampling site were measured monthly at approximately the same time of day. The sampling was carried out over the entire period from spring to winter, in order to capture the impact of temperature variations on production and emission of GHG.

\subsection{Sampling and analysis methods}

\subsubsection{Sampling on nonaerated surface}

A closed chamber technique was used to measure fluxes from nonaerated liquid surfaces (Czepiel et al., 1995). A stainless steel enclosure $(h=38.5 \mathrm{~cm}, \Phi=42.5 \mathrm{~cm})$ was

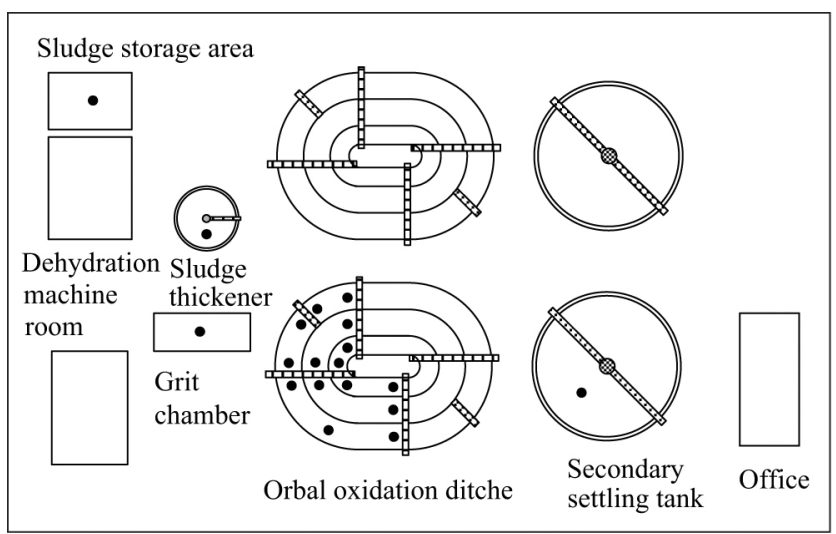

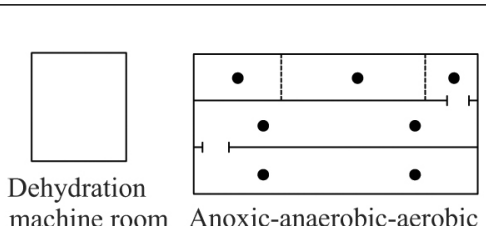

machine room Anoxic-anaerobic-aerobic

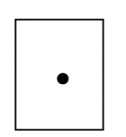

Grit chamber

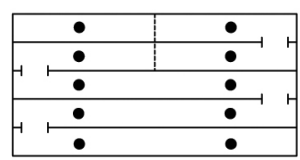

Anaerobic-anoxic-aerobic

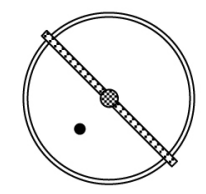

Secondary settling tank

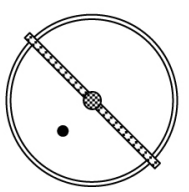

Secondary settling tank

Fig. 1 Schematic diagram of two wastewater treatment plants. • sampling location.

Table 1 Operational parameters of wastewater treatment processes

\begin{tabular}{llll} 
& Orbal oxidation ditches process & Reversed $\mathrm{A}^{2} \mathrm{O}$ process & $\mathrm{A}^{2} \mathrm{O}$ process \\
\hline Capacity $\left(\times 10^{4} \mathrm{~m}^{3} /\right.$ day) & 7 & 23 & 23 \\
Wastewater source & Domestic, industrial & Domestic & Domestic \\
HRT (hr) & 10 & 15 & 15 \\
SRT (day) & 12 & 8 & 14 \\
Sludge return ratio $\left(R_{1}\right)(\%)$ & 100 & 100 & 100 \\
Mixed liquid return ratio $\left(R_{2}\right)(\%)$ & No & No & 300 \\
Sludge treatment & Sludge thickening and mechanical dewatering. & Mechanical dewatering. & Mechanical dewatering \\
\hline
\end{tabular}


floated on the liquid surface with a thermistor mounted inside the enclosure to measure the enclosed air temperature. Floats were fastened to the enclosure sides, and the chamber was manually held in place during sampling to minimize chamber movement due to surface turbulence. A battery-operated blower circulated the air within the enclosure and through a closed loop of hose from which headspace air samples were withdrawn. Samples were collected in 60-mL polypropylene syringes at 3-min intervals over $9 \mathrm{~min}$. The gas flux, $E\left(\mu \mathrm{g} /\left(\mathrm{m}^{2} \cdot \mathrm{hr}\right)\right)$, from the liquid surface in the static chamber was calculated by:

$E=(V / A) \rho(\Delta c / \Delta t)$

where, $V\left(\mathrm{~m}^{3}\right)$ is the volume of the chamber, $A\left(\mathrm{~m}^{2}\right)$ is the enclosed surface area, $\rho\left(\mathrm{mol} / \mathrm{m}^{3}\right)$ is the density of the gas at the temperature recorded in the chamber, and $\Delta c / \Delta t$ is the gas concentration in the chamber during the sampling period.

\subsubsection{Sampling from aerated surface}

A bag technique was used to measure methane fluxes from aerated liquid surfaces (Czepiel et al., 1995). A 40 $\mathrm{L}$ polyethylene sampling bag, fastened to the inside of a rubber support frame, was used to collect samples from $0.14 \mathrm{~m}^{2}$ of the water surface. To collect samples, the bag was first collapsed and emptied of ambient air, and then the rubber support frame was immersed several inches into the water. Dissolved gases within the liquid, transferred mechanically to the distributed air by diffusion, then filled the collection bag. When the bag was filled, the sampled gas was transferred to another $100 \mathrm{~mL}$ sampling bag. The gas flux, $F\left(\mu \mathrm{g} /\left(\mathrm{m}^{2} \cdot \mathrm{hr}\right)\right)$, was calculated by:

$F=\rho c Q / A$

where, $\rho\left(\mathrm{mol} / \mathrm{m}^{3}\right)$ is the density of the gases at the sampling temperature, $c(\mathrm{mg} / \mathrm{L})$ is the sample gas concentration, $Q\left(\mathrm{~m}^{3} / \mathrm{min}\right)$ is the total diffuse air flow, and $A\left(\mathrm{~m}^{2}\right)$ is the total surface area.

\subsubsection{Dissolved gas sampling}

To collect samples of gas dissolved in wastewater, the head space gas method was used as described by Kimochi et al. (1998). $30 \mathrm{~mL}$ each of water and argon gas were sealed into a $50-\mathrm{mL}$ syringe, and $1 \mathrm{~mL}$ of $20 \mathrm{mmol} / \mathrm{L}$ mercury(II) chloride was added to prevent biological degradation. After vigorous shaking, the syringe was left at room temperature for $1 \mathrm{hr}$ without moving it. The resulting gas phase in the syringe was collected as a gas sample. Then the dissolved gas concentration could be calculated based on Henry's Law using the equilibrated headspace gas concentration.

\subsubsection{Analytical methods for gases, water and solid samples}

$\mathrm{CO}_{2}$ concentration was determined using a gas chromatograph $(6890 \mathrm{~N}$, Agilent Co. Ltd., USA) with a thermal conductivity detector, while $\mathrm{CH}_{4}$ concentration was determined by the same gas chromatograph with a flame ionization detector. A gas chromatograph (HPChemistation 5890, Agilent Co. Ltd., USA) with an electron capture detector was used to analyze the $\mathrm{N}_{2} \mathrm{O}$ concentration. COD, $\mathrm{NH}_{4}^{+}-\mathrm{N}$ and $\mathrm{TN}$ in both influent and effluent were analyzed according to standard methods (CEPB, 2004).

\subsection{Calculation methods for GHG mass balance}

GHG generation in each unit of the Orbal oxidation ditch can be calculated by Eqs. (3)-(7).

$G_{\mathrm{GT}}=E_{\mathrm{GT}}+C_{\mathrm{GT}} \times Q-C_{\mathrm{In}} \times Q$

$G_{\mathrm{OC}}=E_{\mathrm{OC}}+C_{\mathrm{OC}} \times\left(1+R_{1}\right) Q-C_{\mathrm{GT}} \times Q-C_{\mathrm{SST}} \times R_{1} Q$

$G_{\mathrm{MC}}=E_{\mathrm{MC}}+C_{\mathrm{MC}} \times\left(1+R_{1}\right) Q-C_{\mathrm{OC}} \times\left(1+R_{1}\right) Q$

$G_{\mathrm{IC}}=E_{\mathrm{IC}}+C_{\mathrm{IC}} \times\left(1+R_{1}\right) Q-C_{\mathrm{MC}} \times\left(1+R_{1}\right) Q$

$G_{\mathrm{SST}}=E_{\mathrm{SST}}+C_{\mathrm{SST}} \times\left(1+R_{1}\right) Q-C_{\mathrm{IC}} \times\left(1+R_{1}\right) Q$

where, $G_{\mathrm{GT}}\left(\mathrm{kg} /\right.$ day), $G_{\mathrm{OC}}\left(\mathrm{kg} /\right.$ day), $G_{\mathrm{MC}}(\mathrm{kg} /$ day $), G_{\mathrm{IC}}$ (kg/day) and $G_{\mathrm{SST}}(\mathrm{kg} /$ day) are the $\mathrm{GHG}$ generation amounts in the grit tank, outer channel, middle channel, inner channel and secondary settling tank respectively. $E_{\mathrm{GT}}$ (kg/day), $E_{\mathrm{OC}}(\mathrm{kg} /$ day $), E_{\mathrm{MC}}(\mathrm{kg} /$ day $), E_{\mathrm{IC}}(\mathrm{kg} /$ day $)$ and $E_{\mathrm{SST}}(\mathrm{kg} /$ day) are the GHG emission amounts from the grit tank, outer channel, middle channel, inner channel and secondary settling tank respectively. $C_{\mathrm{GT}}\left(\mathrm{kg} / \mathrm{m}^{3}\right), C_{\mathrm{OC}}$ $\left(\mathrm{kg} / \mathrm{m}^{3}\right), C_{\mathrm{MC}}\left(\mathrm{kg} / \mathrm{m}^{3}\right), C_{\mathrm{IC}}\left(\mathrm{kg} / \mathrm{m}^{3}\right)$ and $C_{\mathrm{SST}}\left(\mathrm{kg} / \mathrm{m}^{3}\right)$ are the dissolved GHG concentrations in the grit tank, outer channel, middle channel, inner channel and secondary settling tank respectively. $Q\left(\mathrm{~m}^{3} /\right.$ day) is the influent flow rate; $C_{\mathrm{In}}\left(\mathrm{kg} / \mathrm{m}^{3}\right)$ is the dissolved GHG concentration in the influent; $R_{1}(\%)$ is the sludge return ratio.

GHG generation in each unit of the reversed $\mathrm{A}^{2} \mathrm{O}$ process can be calculated by Eqs. (8)-(12).

$G_{\mathrm{GT}}=E_{\mathrm{GT}}+C_{\mathrm{GT}} \times Q-C_{\mathrm{In}} \times Q$

$G_{\mathrm{Ax}}=E_{\mathrm{Ax}}+C_{\mathrm{Ax}} \times\left(40 \%+R_{1}\right) Q-$ $C_{\mathrm{GT}} \times 40 \% Q-C_{\mathrm{SST}} \times R_{1} Q$ 


$$
\begin{aligned}
G_{\mathrm{An}}= & E_{\mathrm{An}}+C_{\mathrm{An}} \times\left(1+R_{1}\right) Q- \\
& C_{\mathrm{Ax}} \times\left(40 \%+R_{1}\right) Q-C_{\mathrm{GT}} \times 60 \% Q
\end{aligned}
$$$$
G_{\mathrm{Ae}}=E_{\mathrm{Ae}}+C_{\mathrm{Ae}} \times\left(1+R_{1}\right) Q-C_{\mathrm{An}} \times\left(1+R_{1}\right) Q
$$

$G_{\mathrm{SST}}=E_{\mathrm{SST}}+C_{\mathrm{SST}} \times\left(1+R_{1}\right) Q-C_{\mathrm{Ae}} \times\left(1+R_{1}\right) Q$

where, $G_{\mathrm{Ax}}(\mathrm{kg} /$ day $), G_{\mathrm{An}}(\mathrm{kg} /$ day $)$ and $G_{\mathrm{Ae}}(\mathrm{kg} /$ day $)$ are the GHG generation amounts in the anoxic, anaerobic and aerobic areas respectively. $E_{\mathrm{Ax}}(\mathrm{kg} / \mathrm{day}), E_{\mathrm{An}}(\mathrm{kg} /$ day $)$ and $E_{\mathrm{Ae}}(\mathrm{kg} /$ day $)$ are the GHG emission amounts from the anoxic, anaerobic and aerobic areas respectively. $C_{\mathrm{Ax}}$ $\left(\mathrm{kg} / \mathrm{m}^{3}\right), C_{\mathrm{An}}\left(\mathrm{kg} / \mathrm{m}^{3}\right)$ and $C_{\mathrm{Ae}}\left(\mathrm{kg} / \mathrm{m}^{3}\right)$ are the dissolved GHG concentrations in the anoxic, anaerobic and aerobic areas respectively.

GHG generation in each unit of the $\mathrm{A}^{2} \mathrm{O}$ process can be calculated by Eqs. (13)-(17).

$$
G_{\mathrm{GT}}=E_{\mathrm{GT}}+C_{\mathrm{GT}} \times Q-C_{\mathrm{In}} \times Q
$$

$G_{\mathrm{An}}=E_{\mathrm{An}}+C_{\mathrm{An}} \times\left(1+R_{1}\right) Q-C_{\mathrm{GT}} \times Q-C_{\mathrm{SST}} \times R_{1} Q$

$$
\begin{aligned}
G_{\mathrm{Ax}}= & E_{\mathrm{Ax}}+C_{\mathrm{Ax}} \times\left(1+R_{1}+R_{2}\right) Q- \\
& C_{\mathrm{An}} \times\left(1+R_{1}\right) Q-C_{\mathrm{Ae}} \times R_{2} Q
\end{aligned}
$$

$G_{\mathrm{Ae}}=E_{\mathrm{Ae}}+C_{\mathrm{Ae}} \times\left(1+R_{1}+R_{2}\right) Q-C_{\mathrm{Ax}} \times\left(1+R_{1}+R_{2}\right) Q$

$G_{\mathrm{SST}}=E_{\mathrm{SST}}+C_{\mathrm{SST}} \times\left(1+R_{1}\right) Q-C_{\mathrm{Ae}} \times\left(1+R_{1}\right) Q$

where, $R_{2}(\%)$ is the mixed liquid return ratio.

\section{Results and discussion}

\subsection{Performance of Orbal oxidation ditch, reversed $\mathrm{A}^{2} \mathrm{O}$ and $\mathrm{A}^{2} \mathrm{O}$ processes}

The performance of the Orbal oxidation ditch, reversed $\mathrm{A}^{2} \mathrm{O}$ and $\mathrm{A}^{2} \mathrm{O}$ processes for wastewater treatment during the nine months of the study are shown in Fig. 2. The ranges of COD concentration in the two WWTPs influents were similar, 306-689 mg/L for the oxidation ditch process and $353-687 \mathrm{mg} / \mathrm{L}$ for the reversed $\mathrm{A}^{2} \mathrm{O}$ process and $\mathrm{A}^{2} \mathrm{O}$ processes, and the efficiencies of $\mathrm{COD}$ removal were generally above $90 \%$. $\mathrm{NH}_{4}^{+}-\mathrm{N}$ and $\mathrm{TN}$ concentrations
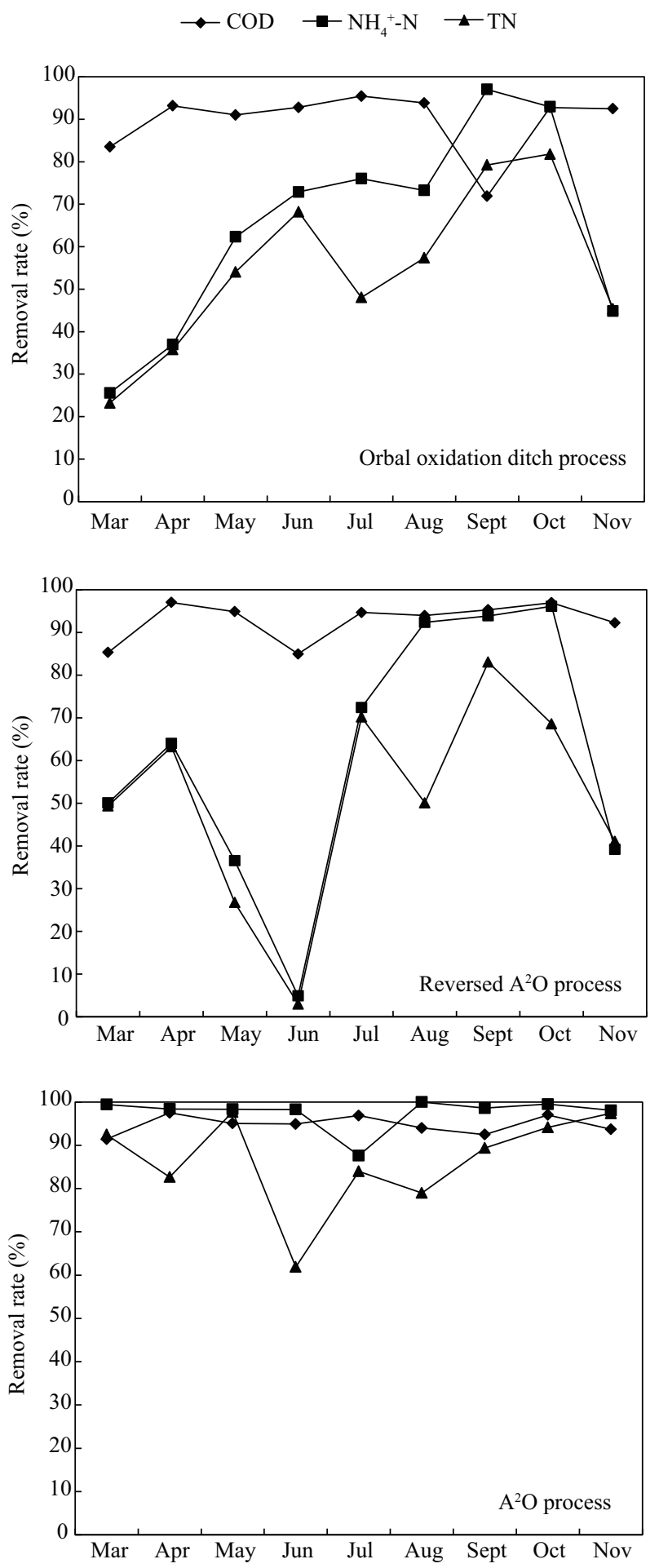

Fig. 2 Removal efficiency of COD, $\mathrm{NH}_{4}{ }^{+}-\mathrm{N}$ and TN.

in the oxidation ditch process influent were 43.0-87.1 $\mathrm{mg} / \mathrm{L}$ and $56.0-90.8 \mathrm{mg} / \mathrm{L}$ respectively, and a remarkable variation trend for their removal efficiencies was observed in different months. The influents of the reversed $\mathrm{A}^{2} \mathrm{O}$ process and $\mathrm{A}^{2} \mathrm{O}$ process were the same, with 38.8-91.3 $\mathrm{mg} / \mathrm{L}$ of $\mathrm{NH}_{4}^{+}-\mathrm{N}$ and $40.3-98.8 \mathrm{mg} / \mathrm{L}$ of TN. Their removal efficiencies were unstable. 


\subsection{Emission characteristics of $\mathrm{CO}_{2}, \mathrm{CH}_{4}$ and $\mathrm{N}_{2} \mathrm{O}$ in treatment processes}

The emission fluxes of $\mathrm{CO}_{2}, \mathrm{CH}_{4}$ and $\mathrm{N}_{2} \mathrm{O}$ from three full-scale wastewater treatment processes are presented in Fig. 3. Although the processes were different, the units presenting high GHG emission fluxes were remarkably similar. The highest $\mathrm{CO}_{2}$ emission fluxes occurred in the aerobic areas of these processes $(\mathbf{F i g}$. 3a-c). The average $\mathrm{CO}_{2}$ emission fluxes in the outer, middle and inner channels of the oxidation ditch were 18.0, 24.2 and 39.5 $\mathrm{g} /\left(\mathrm{m}^{2} \cdot \mathrm{hr}\right)$ respectively. The average $\mathrm{CO}_{2}$ emission fluxes in the aerobic areas of the reversed $\mathrm{A}^{2} \mathrm{O}$ process and $\mathrm{A}^{2} \mathrm{O}$ process were 42.5 and $68.2 \mathrm{~g} /\left(\mathrm{m}^{2} \cdot \mathrm{hr}\right)$ respectively. The $\mathrm{CO}_{2}$ emission fluxes from the secondary settling tanks could be ignored, being less than $0.4 \mathrm{~g} /\left(\mathrm{m}^{2} \cdot \mathrm{hr}\right)$. Hardly any $\mathrm{CO}_{2}$ was emitted from the anaerobic and anoxic areas of the reversed $\mathrm{A}^{2} \mathrm{O}$ process and $\mathrm{A}^{2} \mathrm{O}$ process. The $\mathrm{CO}_{2}$ emission fluxes of each unit had seasonal differences.

The highest $\mathrm{CH}_{4}$ emission fluxes occurred in the grit tank (Fig. 3d-f). The average $\mathrm{CH}_{4}$ emission flux from the grit tank of the oxidation ditch was $0.33 \mathrm{~g} /\left(\mathrm{m}^{2} \cdot \mathrm{hr}\right)$. The reversed $\mathrm{A}^{2} \mathrm{O}$ process and $\mathrm{A}^{2} \mathrm{O}$ process shared one grit tank, in which the average $\mathrm{CH}_{4}$ emission flux was $2.2 \mathrm{~g} /\left(\mathrm{m}^{2} \cdot \mathrm{hr}\right)$. Theoretically, $\mathrm{CH}_{4}$ is produced in anaerobic conditions. However, an interesting phenomenon was observed in this study, which the $\mathrm{CH}_{4}$ emission flux in the forepart of the aerobic area was distinctly higher than that of the anaerobic area (Fig. 3e and $\mathbf{f})$.

$\mathrm{N}_{2} \mathrm{O}$ is usually produced in biological nitrogen removal processes. Fig. $3 g-\mathbf{i}$ shows the monitored results of $\mathrm{N}_{2} \mathrm{O}$ emission fluxes in the three full-scale wastewater treatment processes. In the oxidation ditch, the highest $\mathrm{N}_{2} \mathrm{O}$ emission flux appeared mainly in the middle and inner channels, with mean emission fluxes of $3.9 \times 10^{-2}$ and $7.9 \times 10^{-2}$ $\mathrm{g} /\left(\mathrm{m}^{2} \cdot \mathrm{hr}\right)$, respectively. In the reversed $\mathrm{A}^{2} \mathrm{O}$ process and $\mathrm{A}^{2} \mathrm{O}$ process, the highest $\mathrm{N}_{2} \mathrm{O}$ emission fluxes also appeared in aerobic areas, with mean fluxes of $2.1 \times 10^{-2}$ and $2.7 \times 10^{-2} \mathrm{~g} /\left(\mathrm{m}^{2} \cdot \mathrm{hr}\right)$, respectively, but the $\mathrm{N}_{2} \mathrm{O}$ emission fluxes from the anoxic areas were very low. Moreover, the $\mathrm{N}_{2} \mathrm{O}$ emission fluxes in the aerobic areas showed a similar tendency in the reversed $\mathrm{A}^{2} \mathrm{O}$ process and $\mathrm{A}^{2} \mathrm{O}$ process, increasing from the first sampling point and then decreasing at the last one. The cause of this phenomenon is still unknown.

The GHG mass balance of the three wastewater treatment processes is shown in Fig. 4. The results revealed that all maximum emission amounts of $\mathrm{CO}_{2}, \mathrm{CH}_{4}$ and $\mathrm{N}_{2} \mathrm{O}$ in the three wastewater treatment processes appeared in the aerobic areas. Through analysis of the GHG mass balance, it was found that the GHG generation amount and GHG emission amount in each unit was not consistent, and the flow of dissolved GHG in the wastewater treatment processes and aerators might be the main reason explaining this phenomenon.

\subsection{GHG emission factors}

Based on the monitoring and calculation results, the GHG emission factors of the three wastewater treatment pro-
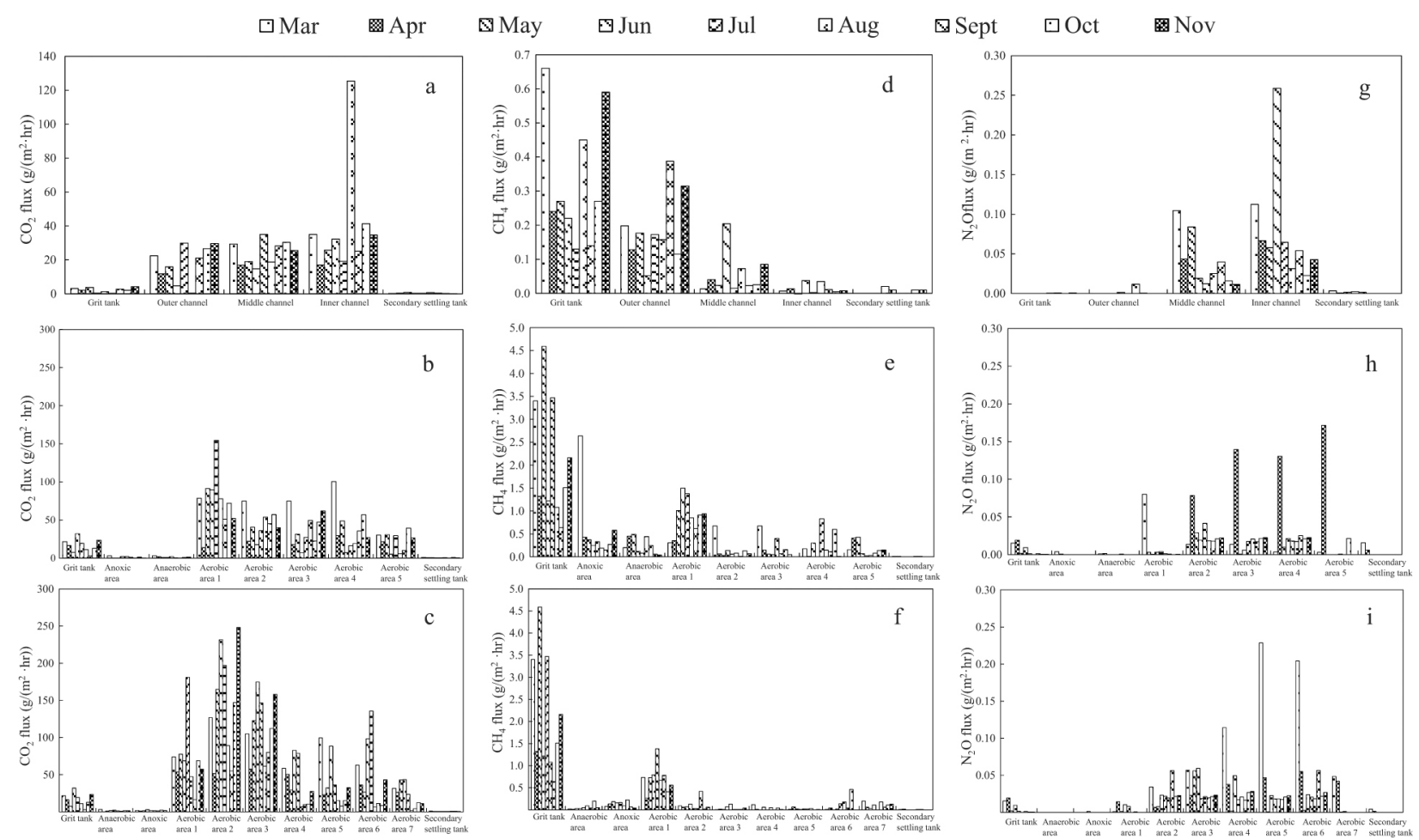

Fig. 3 Emission fluxes of $\mathrm{CO}_{2}, \mathrm{CH}_{4}$, and $\mathrm{N}_{2} \mathrm{O}$ from Orbal oxidation ditch process (a, d, g), reversed $\mathrm{A}^{2} \mathrm{O}$ process (b, e, h) and $\mathrm{A}^{2} \mathrm{O}$ process (c, f, i). 


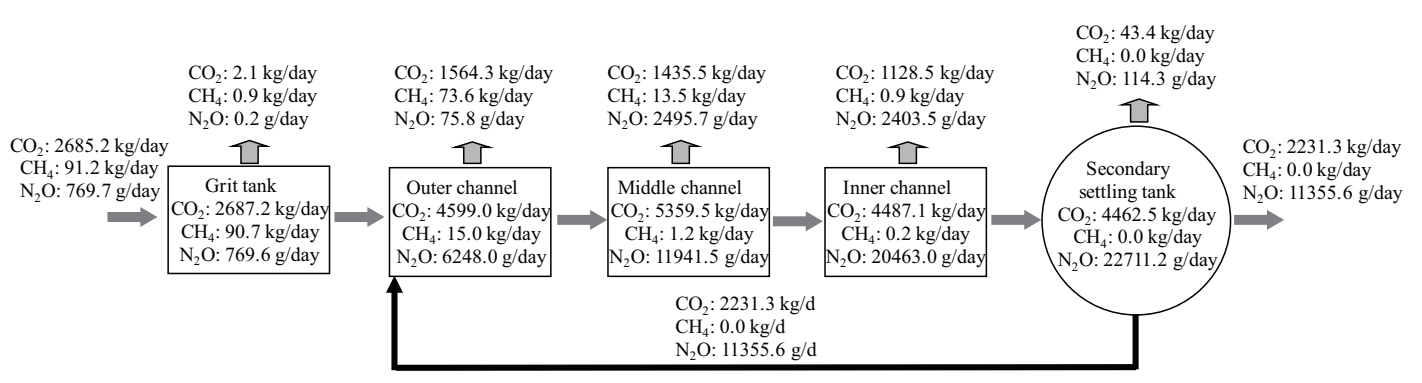

Orbal oxidation ditch process

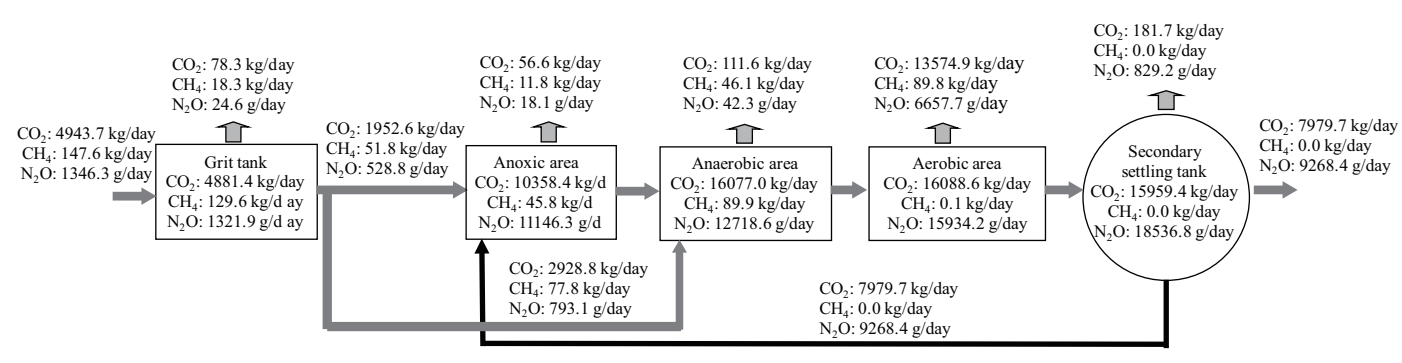

Reversed $\mathrm{A}^{2} \mathrm{O}$ process

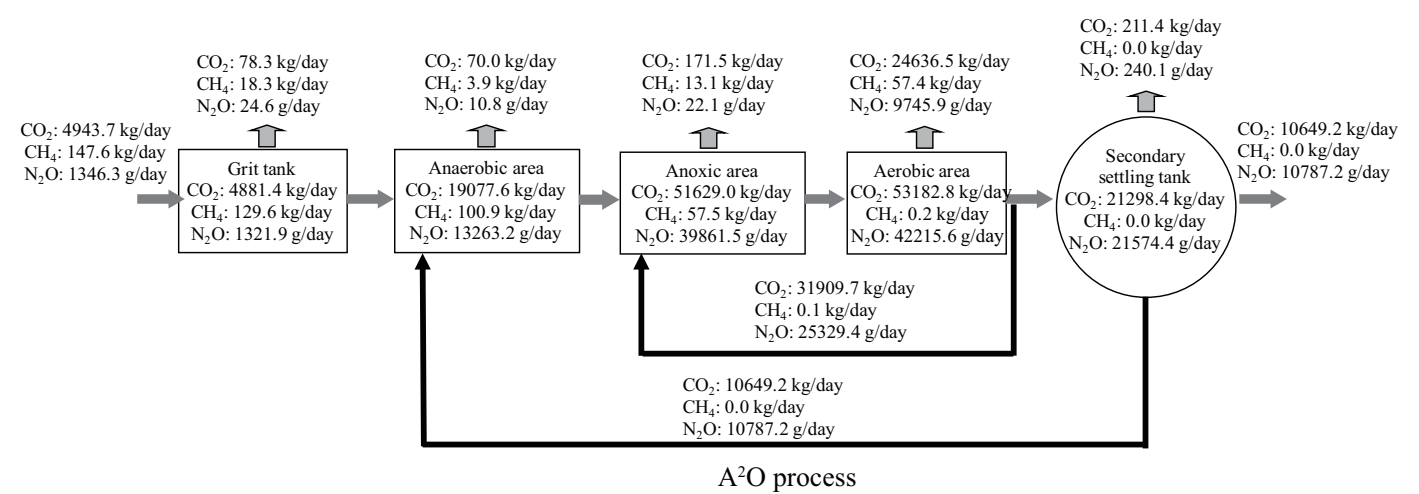

Fig. 4 Schematic diagram of GHG mass balance in the three wastewater treatment processes.

cesses were determined (Fig. 5), which include the GHG released into the air and dissolved in the effluent of the secondary settling tank. It can be seen from Fig. 5a-c that the GHG emission factors of the three wastewater treatment processes varied every month, but most of them were bound within a range. The range and average value of the GHG emission factors of the three wastewater treatment processes are summarized in Table 2.

Both based on removed pollutant amounts and wastew- ater flow, the $\mathrm{A}^{2} \mathrm{O}$ process presented the highest $\mathrm{CO}_{2}$ emission factor and the lowest $\mathrm{CH}_{4}$ and $\mathrm{N}_{2} \mathrm{O}$ emission factors among the three investigated processes. The highest $\mathrm{CH}_{4}$ and $\mathrm{N}_{2} \mathrm{O}$ emission factors were observed from the Orbal oxidation ditch process. In addition, the order of GHG emission factor (for $\mathrm{CO}_{2}$-eq) for the treatment processes was: $\mathrm{A}^{2} \mathrm{O}$ process $>$ Orbal oxidation ditch process $>$ reversed $\mathrm{A}^{2} \mathrm{O}$ process.

Table 2 GHG emission factors of the three wastewater treatment processes

\begin{tabular}{llll} 
& Orbal oxidation ditch & Reversed $\mathrm{A}^{2} \mathrm{O}$ & $\mathrm{A}^{2} \mathrm{O}$ \\
\hline $\mathrm{CO}_{2}$ emission factor $\left(\mathrm{g} \mathrm{CO}_{2} / \mathrm{kg} \mathrm{COD}_{\text {removed }}\right)$ & $146.2-377.5(261.3)^{*}$ & $160.6-294.4(227.3)$ & $216.2-496.0(319.3)$ \\
$\mathrm{CH}_{4}$ emission factors $\left(\mathrm{g} \mathrm{CH}_{4} / \mathrm{kg} \mathrm{COD}_{\text {removed }}\right)$ & $2.85-3.95(3.3)$ & $0.7-2.4(1.4)$ & $0.5-1.2(0.9)$ \\
$\mathrm{N}_{2} \mathrm{O}$ emission factors $\left(\mathrm{g} \mathrm{N}_{2} \mathrm{O} / \mathrm{kg} \mathrm{TN}_{\text {removed }}\right)$ & $0.8-8.8(3.6)$ & $0.6-5.9(2.3)$ & $0.4-1.5(0.8)$ \\
$\mathrm{CO}_{2}$ emission factor $\left(\mathrm{g} \mathrm{CO}_{2} / \mathrm{m}^{3}\right.$ wastewater $)$ & $59.3-112.2(89.7)$ & $51.8-116.0(87.0)$ & $79.6-240.1(155.7)$ \\
$\mathrm{CH}_{4}$ emission factors $\left(\mathrm{g} \mathrm{CH}_{4} / \mathrm{m}^{3}\right.$ wastewater $)$ & $0.9-1.4(1.2)$ & $0.3-1.0(0.7)$ & $0.3-0.5(0.4)$ \\
$\mathrm{N}_{2} \mathrm{O}$ emission factors $\left(\mathrm{g} \mathrm{N}_{2} \mathrm{O} / \mathrm{m}^{3}{ }_{\text {wastewater }}\right)$ & $0.1-0.4(0.2)$ & $0.2 \times 10^{-1}-0.2\left(0.7 \times 10^{-1}\right)$ & $0.3 \times 10^{-1}-0.5 \times 10^{-1}\left(0.6 \times 10^{-1}\right)$ \\
$\mathrm{GHG}^{-1}$ emission factors $\left(\mathrm{g} \mathrm{CO}_{2}-\mathrm{eq} / \mathrm{m}^{3}\right.$ wastewater $)$ & $133.0-239.7(176.5)$ & $80.1-232.5(123.8)$ & $101.5-285.4(182.7)$ \\
\hline
\end{tabular}

$\mathrm{CO}_{2}$-eq is carbon dioxide equivalent. ${ }^{*}$ The values in brackets are average. 

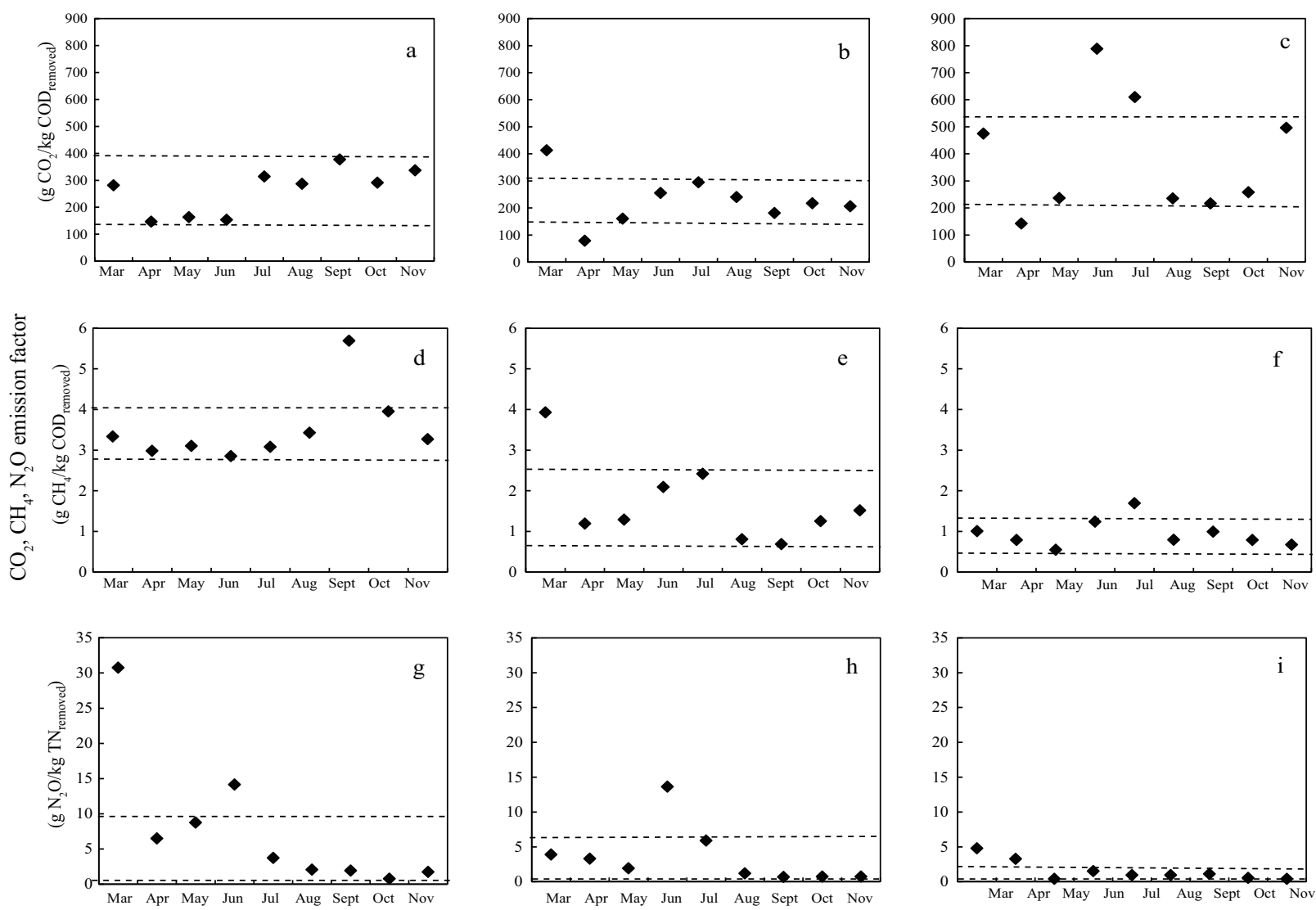

Fig. $5 \mathrm{CO}_{2}, \mathrm{CH}_{4}$, and $\mathrm{N}_{2} \mathrm{O}$ emission factors from oxidation ditch process (a, d, g), reversed $\mathrm{A}^{2} \mathrm{O}$ process $(b, e, h)$ and $\mathrm{A}^{2} \mathrm{O}$ process (c, $\left.\mathrm{f}, \mathrm{i}\right)$.

\section{Conclusions}

The emission characteristics of $\mathrm{CO}_{2}, \mathrm{CH}_{4}$ and $\mathrm{N}_{2} \mathrm{O}$ were investigated in three full-scale wastewater treatment processes. Conclusions are as follows: Although the processes are different, the units presenting high GHG emission fluxes were remarkably similar, namely the highest $\mathrm{CO}_{2}$ and $\mathrm{N}_{2} \mathrm{O}$ emission fluxes occurred in the aerobic area, and the highest $\mathrm{CH}_{4}$ emission fluxes occurred in the grit tank. Moreover, all maximum emission amounts of $\mathrm{CO}_{2}$, $\mathrm{CH}_{4}$ and $\mathrm{N}_{2} \mathrm{O}$ appeared in the aerobic areas of the three wastewater treatment processes. The aerators and circulating flow of dissolved GHG in the wastewater treatment processes had a great impact on GHG emission, which resulted in a discrepancy between the GHG generation amount and GHG emission amount in each unit. Both based on pollutant removal amount and wastewater flow, the same order of GHG emission factors was observed for these three treatment processes. The highest $\mathrm{CO}_{2}$ emission factor was calculated for the $\mathrm{A}^{2} \mathrm{O}$ process, and the highest $\mathrm{CH}_{4}$ and $\mathrm{N}_{2} \mathrm{O}$ emission factor was found for the Orbal oxidation ditch process. 176.5, 123.8 and $182.7 \mathrm{~g} \mathrm{CO}_{2}$-eq GHG would be produced from $1.0 \mathrm{~m}^{3}$ wastewater for the Orbal oxidation ditch, reversed $\mathrm{A}^{2} \mathrm{O}$ and $\mathrm{A}^{2} \mathrm{O}$ processes, respectively.

\section{Acknowledgments}

This work was supported by the National Natural Science Foundation of China (No. 51138009).

R E F E R E N C E S

Ahn, J. H., Kim, S., Park, H., Rahm, B., Pagilla, K., Chandran, K., 2010. $\mathrm{N}_{2} \mathrm{O}$ emissions from activated sludge processes, 2008-2009: Results of a national monitoring survey in the United States. Environ. Sci. Technol. 44, 4505-4511.

CEPB (China Environmental Protection Bureau), 2004. Standard Methods for the Examination of Water and Wastewater (2002), 4th ed. Chinese Environmental Science Press, Beijing.

Chiu, Y. C., Chung, M. S., 2000. BNP test to evaluate the influence of $\mathrm{C} / \mathrm{N}$ ratio on $\mathrm{N}_{2} \mathrm{O}$ production in biological denitrification. Water Sci. Technol. 42, 23-27.

Czepiel, P. M., Crill, P. M., Harriss, R. C., 1995. Nitrous oxide emissions from municipal wastewater treatment. Environ. Sci. Technol. 29, 2352-2356.

Czepiel, P. M., Crill, P. M., Harriss, R. C., 1993. Methane emissions from municipal wastewater treatment processes. Environ. Sci. Technol. 46, 2472-2477.

Doorm, M. R. J., Strait, R. P., Barnard, W. R., Eklund, B., 1997. Estimates of Global Greenhouse Gas Emissions from Industrial and Domestic Wastewater Treatment, EPA-600/R-97-019. US EPA, Air Pollution Prevention and Control Division, Washington, DC. 
Eklund, B., LaCosse, J., 1998. Field Measurement of Greenhouse Gas Emission Rates and Development of Emission Factors for Wastewater Treatment, EPA/600/SR-97/094. US EPA, Air Pollution Prevention and Control Division.

Flores-Alsina, X., Corominas, L., Snip, L., Vanrolleghem, P. A., 2011. Including greenhouse gas emissions during benchmarking of wastewater treatment plant control strategies. Water Res. 45, 47004710 .

Foley, J., de Haas, D., Yuan, Z. G., Lant, P., 2010. Nitrous oxide generation in full-scale biological nutrient removal wastewater treatment plants. Water Res. 44, 831-844.

Forster-Carneiro, T., Perez, M., Romero, L. I., 2008. Thermophilic anaerobic digestion of source-sorted organic fraction of municipal solid waste. Bioresour. Technol. 99, 6763-6770.

IPCC, 1996. Revised 1996 IPCC Guide Lines for National Greenhouse Gas Inventories: Workbook. Japan, Hayama: IPCC.

Kampschreur, M. J., Tan, N. C. G., Kleerebezem, R., Picioreanu, C., Jetten, M. S. M., Loosdrecht, M. C. M., 2008a. Effect of dynamic process conditions on nitrogen oxides emission from a nitrifying culture. Environ. Sci. Technol. 42, 429-435.

Kampschreur, M. J., Temmink, H., Kleerebezem, R., Jetten, M. S. M., van Loosdrecht, M. C. M., 2009. Nitrous oxide emission during wastewater treatment. Water Res. 43, 4093-4103.

Kampschreur, M. J., van der Star, W. R. L., Wielders, H. A., Mulder, J. W., Jetten, M. S. M., van Loosdrecht, M. C. M., 2008b. Dynamics of nitric oxide and nitrous oxide emission during full-scale reject water treatment. Water Res. 42, 812-826.

Keller, J., Hartley, K., 2003. Greenhouse gas production in wastewater treatment: process selection is the major factor. Water Sci. Technol. 47, 43-48.

Kimochi, Y., Inamori, Y., Mizuochi, M., Xu, K. Q., Matsumura, M., 1998. Nitrogen removal and $\mathrm{N}_{2} \mathrm{O}$ emission in a full scale domestic wastewater treatment plant with intermittent aeration. J. Fermen. Bioeng. 86, 202-206.

Li, Q. H., Li, P., Zhu, P. P., Wu, J. H., Liang, S. Z., 2008. Effects of exogenous organic carbon substrates on nitrous oxide emissions during the denitrification process of sequence batch reactors. Environ. Eng. Sci. 25, 1221-1228.

Metcalf \& Eddy, 2002. Wastewater Engineering: Treatment and Reuse, fourth ed. McGraw Hill Higher Education. New York, USA.

Park, K. Y., Inamori, Y., Mizuochi, M., Ahn, K. H., 2000. Emission and control of nitrous oxide from a biological wastewater treatment system with intermittent aeration. J. Bios. Bioeng. 90, 247-252.

Sahely, H. R., MacLean, H. L., Monteith, H. D., Bagley, D. M., 2006. Comparison of on-site and upstream greenhouse gas emissions from Canadian municipal wastewater treatment facilities. J. Environ. Eng. Sci. 5, 405-415.

Tallec, G., Garnier, J., Billen, G., Gousailles, M., 2008. Nitrous oxide emissions from denitrifying activated sludge of urban wastewater treatment plants, under anoxia and low oxygenation. Bioresour. Technol. 99, 2200-2209.

Wang, J. H., Zhang, J., Xie, H. J., Qi, P. Y., Ren, Y. G., Hu, Z., 2011. Methane emissions from a full-scale A/A/O wastewater treatment plant. Bioresour. Technol. 102, 5479-5485.

Yoshida, H., Tokumoto, H., Ishii, K., Ishii, R., 2009. Efficient, high-speed methane fermentation for sewage sludge using subcritical water hydrolysis as pretreatment. Bioresour. Technol. 100, 2933-2939.

Zeng, R. J., Yuan, Z. G., Keller, J., 2003. Enrichment of denitrifying glycogen-accumulating organisms in anaerobic/anoxic activated sludge system. Biotechnol. Bioeng. 81, 397-404.

Zhu, B. N., Gikas, P., Zhang, R. H., Lord, J., Jenkins, B., Li, X. J., 2009. Characteristics and biogas production potential of municipal solid wastes pretreated with a rotary drum reactor. Bioresour. Technol. 100, 1122-1129. 